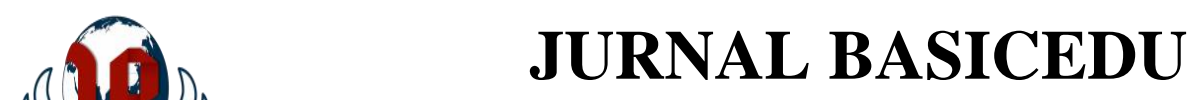

Volume 5 Nomor 2 Tahun 2021 Halaman 887-894

Research \& Learning in Elementary Education https://jbasic.org/index.php/basicedu

PAHLAWAN

\title{
Meta Analisis Pengaruh Pendekatan Matematika Realistik Terhadap Kemampuan Berpikir Kritis Pada Matematika Siswa di Sekolah Dasar
}

\author{
Fadila Nawang Utami ${ }^{1 凶}$, Endang Indarini ${ }^{2}$ \\ Pendidikan Guru Sekolah Dasar, Universitas Kristen Satya Wacana, Indonesia ${ }^{1,2}$ \\ E-mail: 292017108@ @student.uksw.edu ${ }^{1}$, endang.indarini@uksw.edu ${ }^{2}$
}

\begin{abstract}
Abstrak
Penelitian ini bertujuan untuk mengetahui seberapa besar pengaruh Pendekatan Matematika Realistik dari berbagai penelitian eksperimen yang dipublikasikan terhadap kemampuan berpikir kritis pada matematika siswa Sekolah Dasar. Penelitian yang dilakukan merupakan penelitian meta analisis. Langkah pertama yang dilakukan pada penelitian ini yaitu merumuskan masalah langkah kedua mencari hasil penelitian jurnal online melalui Google Cendekia. Langkah ketiga menganalisis data penelitian dan langkah terakhir laporan hasil penelitian. Sesuai dengan pencarian data, peneliti menemukan 10 jurnal yang sesuai. Pendekatan Matematika Realistik memperlihatkan rata-rata hasil pretest dan posttest mengalami peningkatan sebesar $31,5 \%$. Uji prasyarat dengan menggunakan uji normalitas, uji homogenitas, dan uji linearitas dapat memperlihatkan bahwa Pendekatan Matematika Realistik dapat berdistribusi normal, homogen dan linear. Uji normalitas dengan menggunakan teknik Shapiro-Wilk memperlihatkan bahwa nilai Sig. >0,05. Uji homogenitas data pretest dan posttest sebesar $0,103>0,05$. Uji linearitas menunjukkan nilai Sig. $>0,05$. Uji Ancova menggunakan Univariate menunjukkan nilai Sig. 0,047 < 0,05 yang artinya Ho ditolak dan Ha diterima. Pada uji effect size yang memperlihatkan bahawa Pendekatan Matematika Realistik memberikan pengaruh tergolong sedang pada peningkatan kemampuan berpikir kritis matematika siswa SD.
\end{abstract}

Kata Kunci: Pendekatan Matematika Realistik, Berpikir Kritis.

\begin{abstract}
This study aims to determine how much influence the Realistic Mathematical Approach from various published experimental studies has on the critical thinking skills of elementary school students. This research is a meta-analysis research. The first step in this research is to formulate a problem. The second step is to find the results of online journal research through Google Scholar. The third step is to analyze the research data and the final step is to report the research results. In accordance with the data search, the researcher found 10 suitable journals. The Realistic Mathematical Approach shows that the average pretest and posttest results have increased by $31.5 \%$. The prerequisite test using the normality test, homogeneity test, and linearity test can show that the Realistic Mathematical Approach can be normally distributed, homogeneous and linear. The normality test using the Shapiro-Wilk technique shows that the Sig. >0.05. The pretest and posttest data homogeneity test was 0.103>0.05. The linearity test shows the Sig. >0.05. Ancova test using Univariate shows the value of Sig. 0.047<0.05, which means that Ho is rejected and Ha is accepted. In the effect size test, which shows that the Realistic Mathematical Approach has a moderate effect on improving the critical thinking skills of elementary school students.
\end{abstract}

Keywords: Realistic Mathematical Approach, Critical Thinking.

Copyright (c) 2021 Fadila Nawang Putri, Endang Indarini

Corresponding author :

Email:292017108@student.uksw.edu

DOI : https://doi.org/10.31004/basicedu.v5i2.852

ISSN 2580-3735 (Media Cetak)

ISSN 2580-1147 (Media Online)

Jurnal Basicedu Vol 5 No 2 Tahun 2021

p-ISSN 2580-3735 e-ISSN 2580-1147 


\section{PENDAHULUAN}

Pembelajaran merupakan hubungan timbal balik antara siswa dengan guru yang bertujuan untuk mencapai pendidikan nasional. Di dalam proses pembelajaran siswa tidak hanya dilihat sebagai penerima pasif, tetapi juga diberikan kesempatan untuk menemukan kembali sebuah konsep atau ide dibawah bimbingan guru.

Untuk memperoleh hasil yang maksimal dibutuhkan strategi yang benar dan baik dalam proses pembelajaran. Sebagaimana dalam (Peraturan Menteri Pendidikan dan Kebudayaan No 22 Tahun 2016) tentang standar proses, bahwa dalam proses pembelajaran pada satuan pendidikan harus di selenggarakan secara interaktif, menantang, menyenangkan, memotivasi siswa untuk aktif terlibat dan menyediakan tempat yang pas bagi ide, kemandirian dan kreativitas siswa sesuai dengan minat, bakat dan perkembangan fisik serta psikologi siswa. Sehingga, pembelajaran memiliki tujuan untuk mensukseskan pendidikan di Indonesia, salah satunya pendidikan di Sekolah Dasar (SD).

Pelaksanaan pembelajaran di Sekolah Dasar/Madrasah Ibtidaiyah (SD/MI) dalam K13 di lakukan dengan pendekatan tematik terpadu, kecuali mata pelajaran matematika dan PJOK sebagai mata pelajaran yang berdiri sendiri untuk kelas tinggi (Permendikbud No. 24 Tahun 2016). Hal ini terjadi karena materi pembelajaran matematika pada buku tematik K13 dirasa kurang mendalam dibuktikan dalam kemampuan berpikir peserta didik kurang kreatif sehingga mempengaruhi hasil belajar dan kemampuan berpikir kritis matematika peserta didik.

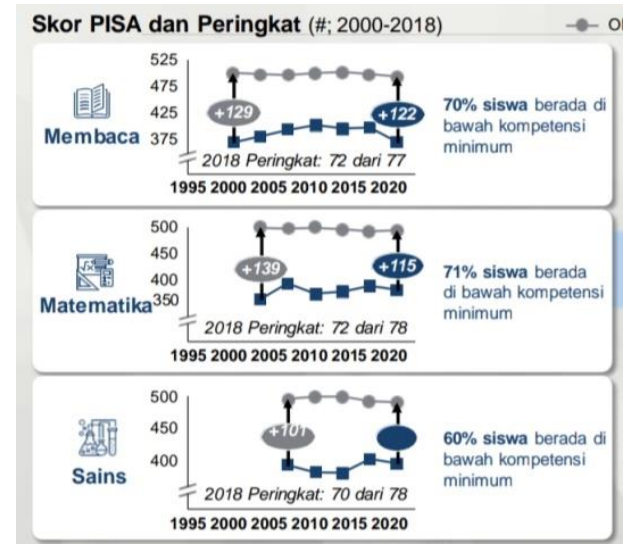

Grafik 1. Hasil PISA tahun 2020

Dari yang tertera pada diagram Programme for International Student Assesment (PISA) dalam bidang matematika pada tahun 2020 menampilkan nilai matematika di Indonesia dengan rata-rata 350 pada tahun 2018 Indonesia berada di peringkat 72 dari 78 negara. $71 \%$ siswa berada di bawah kompetensi minimum. Dengan adanya data hasil studi internasional tersebut dapat dikatakan bahwa prestasi matematika peserta didik di Indonesia berada di peringkat bawah.

Kemampuan berpikir kritis merupakan proses dari berpikir secara tepat, beralasan, reflektif dan terarah dalam setiap pengambilan keputusan yang dapat di percaya (Kusumaningsih, 2011). Sejalan dengan Permendikbud (2013) yang dikembangkan dalam kurikulum 2013 tentang kemampuan 4C yaitu, Collaboration, Creative, Communication, dan Critical Thinking. Yang menuntut peserta didik untuk berpikir secara kritis dalam memahami situasi dan juga kondisi saat pembelajaran dan mampu memecahkan masalah dalam kehidupan sehari-hari.

Dalam meningkatkan kemampuan berpikir kritis siswa hendaknya seorang pendidik mampu menentukan dan menggunakan pendekatan yang efektif dalam proses pembelajaran. Salah satunya adalah Pendekatan Matematika Realistik. Pendekatan matematika realistik adalah salah satu pendekatan matematika 
DOI : https://doi.org/10.31004/basicedu.v5i2.852

yang berorientasi pada keterkaitan antar konsep-konsep matematika dengan pengalaman sehari-hari. Proses pengembangan dari konsep-konsep dan ide-ide dari matematika bermula dari dunia nyata (Wahyudi, 2017). Pembelajaran matematika realistik ini menggunakan masalah kontektual yang merupakan pengganti dari pengenalan konsep benda abstrak. Prosedur dari konsep dan ide dari matematika yang bermula dari dunia nyata. Di dalam dunia nyata tidak berarti konkret secara fisik dan kasat mata, namun juga termasuk yang dapat dibayangkan oleh anak. Prinsip penemuan kembali dapat diinspirasi oleh prosedur-prosedur pemecahan bebas, sedangkan proses penemuan kembali menggunakan matematisasi.

Traffers (Wijaya, 2016) menyebutkan karakteristik dari Pendidikan Matematika Realistik, yaitu:

1. Pemakaian kondisi atau masalah realistik di pakai menjadi awal dalam pembelajaran matematika.

2. Pemakaian model dalam matematisasi pengembangan pendidikan matematika realistik, model dipakai untuk melaksanakan matematisasi dengan progresif.

3. Pemanfaatan hasil kontruksi siswa sebagai sebuah konsep yang ditingkatkan oleh siswa sehingga dalam pendidikan matematika realistik siswa ditempatkan di dalam subjek belajar.

4. Interaksi proses belajar seseorang bukan hanya sebuah proses individu yaitu juga dengan bersamaan merupakan sebuah proses sosial.

5. Keterhubungan antar konsep didalam matematika tidak bersifat sebagian, tetapi mayoritas konsep matematika yang mempunyai hubungan.

Dari penelitian yang telah dilakukan oleh Dwi Wulan Suci, Firman dan Neviyarni (2019) dari hasil menunjukkan bahwa pembelajaran dengan Pendekatan Realistik dapat membantu siwa dalam memahami konsep dalam pembelajaran matematika dan dapat meningkatkan ketrampilan berpikir kritis siswa. Sehingga membuat peneliti untuk melaksanakan penelitian mengenai Pendekatan Matematika Realistik. Oleh karena itu, peneliti melakukan penelitian dengan judul "Meta Analisis Pengaruh Pendekatan Matematika Realistik Terhadap Kemampuan Berpikir Kritis Pada Matematika Siswa di Sekolah Dasar". Penelitian ini dilaksanakan untuk mengetahui "Apakah Pendekatan Matematika Realistic dari berbagai Penelitian Eksperimen yang di Publikasikan Berpengaruh Terhadap Kemampuan Berpikir Kritis Siswa?

\section{METODE PENELITIAN}

Penelitian yang dilakukan merupakan penelitian meta anlisis. Metode meta analisis digunakan untuk merangkum, meringkas dan juga memperoleh inti dari hasil data penelitian sebelumnya. Dalam menentukan populasi jurnal dengan cara mencari melalui jurnal online di Google Cendekia. Kata kunci yang digunakan adalah "Pendekatan Matematika Realistik" dan "Berpikir Kritis". Dari hasil pencarian melalui kata kunci tersebut didapatkan beberapa jurnal yang sesuai dengan penelitian yang dilaksanakan. Dengan adanya data pretest dan posttest dalam bentuk skor presentase rerata dalam jurnal yang didapatkan. Instrument data yang dipakai dengan memberikan kode pada setiap jurnal yang didapatkan.

Teknik analisis data menggunakan uji prasyarat (uji normalitas, uji homogenitas, dan uji linearitas), uji Ancova dengan menggunakan Univariate, dengan menghitung effect size untuk melihat seberapa besar pengaruh dari Pendekatan Matematika Realistik terhadap kemampuan berpikir kritis.

\section{HASIL DAN PEMBAHASAN}

Tahap awal yang dilakukan yaitu merumuskan masalah, mengumpulkan data penelitian melalui pencarian jurnal online yang telah dipublikasikan dalam rentang tahun 2011-2020. Berdasarkan hasil 
DOI : https://doi.org/10.31004/basicedu.v5i2.852

pencarian oleh peneliti mendapatkan 10 jurnal artikel yang relevan. Data hasil analisis dari Pendekatan Matematika Realistik dapat dilihat pada tabel dibawah ini.

Tabel 1. Presentase Peningkatan Kemampuan Berpikir Kritis Siswa dengan Pendekatan Matematika Realistik

\begin{tabular}{ccccc}
\hline No & \multicolumn{4}{c}{ Presentase (\%) } \\
\cline { 2 - 5 } & Kode & Skor & Skor & Peningkatan \\
& Data & Pretest & Posttest & \\
$\mathbf{1}$ & $1 \mathrm{~A}$ & 33,21 & 82,61 & 49,4 \\
$\mathbf{2}$ & $2 \mathrm{~A}$ & 44 & 81,06 & 37,06 \\
$\mathbf{3}$ & $3 \mathrm{~A}$ & 34,78 & 84,78 & 50 \\
$\mathbf{4}$ & $4 \mathrm{~A}$ & 60 & 77 & 17 \\
$\mathbf{5}$ & $5 \mathrm{~A}$ & 63.2 & 70 & 6,8 \\
$\mathbf{6}$ & $6 \mathrm{~A}$ & 45 & 100 & 55 \\
$\mathbf{7}$ & $7 \mathrm{~A}$ & 63,83 & 84,66 & 20,83 \\
$\mathbf{8}$ & $8 \mathrm{~A}$ & 46 & 100 & 54 \\
$\mathbf{9}$ & $9 \mathrm{~A}$ & 64 & 80,62 & 17 \\
$\mathbf{1 0}$ & $10 \mathrm{~A}$ & 65,45 & 73,89 & 8,44 \\
& Rerata & 51.9 & 83.4 & 31.5 \\
\hline
\end{tabular}

Presentase rerata peningkatan berpikir kritis matematika siswa dengan menggunakan Pendekatan Matematika Realistik dari skor terendah 6,8\% dan skor tertinggi sebesar 55\% dengan rerata sebesar 31,5\%. Sesuai dengan presentase skor pretest dan posttest sehingga dapat dikomparasikan. Komparasi hasil pengukuran dapat dilihat pada tabel berikut;

\section{Tabel 2. Komparasi Hasil Pengukuran Kemampuan Berpikir Kritis}

\begin{tabular}{|c|c|c|}
\hline \multirow{2}{*}{ Pengukuran } & \multicolumn{2}{|c|}{ Rata-Rata Skor (Mean) } \\
\cline { 2 - 2 } & $\begin{array}{c}\text { Pendekatan } \\
\text { Matematika } \\
\text { Realistik }\end{array}$ & Selisih \\
\hline Pretest & 51,9 & \multirow{2}{*}{31,5} \\
\hline Posttest & 83,4 & \\
\hline
\end{tabular}

Berdasarkan hasil pengukuran komparasi rata-rata skor pada tabel diatas, skor pretest dan skor posttest mempunayi selisi sebesar 31,5. Berikut ini adalah diagram komparasi antara nilai pretest dan nilai posttest pada Pendekatan Matematika Realistik:

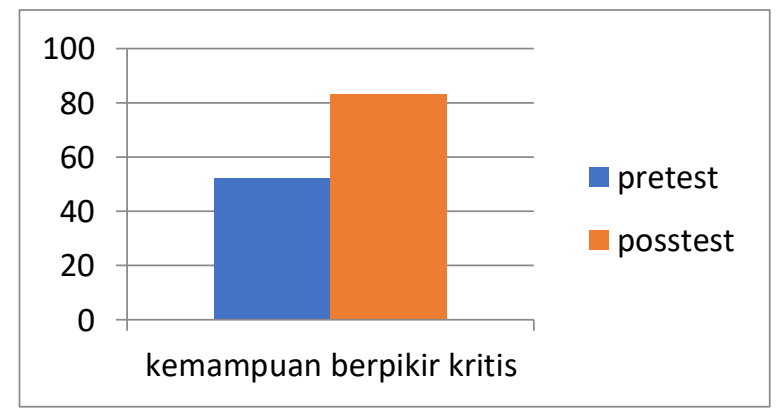

Diagram 1. Diagram Komparasi Data Skor Pretest dan Posttest 
Pada Matematika Siswa di Sekolah Dasar - Fadila Nawang Utami, Endang Indarini

DOI : https://doi.org/10.31004/basicedu.v5i2.852

Sesuai dengan diagram di atas, dapat diartikan bahwa terdapat peningkatan dari skor pretest dan posttest pada Pendekatan Matematika Realistik.

\section{Tabel 3. Uji Normalitas Pendekatan Matematika Realistik}

\begin{tabular}{|l|r|r|r|r|r|c|}
\hline & \multicolumn{3}{|c|}{ Kolmogorov- } & \multicolumn{3}{c|}{ Shapiro-Wilk } \\
\cline { 2 - 7 } & Statistic & Df & Sig. & Statistic & Df & Sig. \\
\hline Posttest & .244 & 10 & .095 & .898 & 10 & .207 \\
Pretest & .239 & 10 & .111 & .848 & 10 & .055 \\
\hline
\end{tabular}

Sesuai dengan tabel diatas dapat dilihat hasil dari uji normalitas skor pretest dan posttest Pendekatan Matematika Realistik. Uji normalitas menggunakan teknik Shapiro-Wilk berbantu SPSS 20.00 for windows dapat diartika bahwa nilai signifikasi > 0,05 maka data berdistribusi normal.

Tabel 4. Uji Homogenitas Skor Pretest dan Posttest Pendekatan Matematika Realistik

\begin{tabular}{|c|c|c|c|}
\hline $\begin{array}{l}\text { Levene } \\
\text { Statistic }\end{array}$ & $\mathrm{df} 1$ & $\overline{d f 2}$ & Sig. \\
\hline 2.948 & 1 & 18 & .103 \\
\hline
\end{tabular}

Tabel di atas memperlihatkan bahwa hasil uji homogenitas dari nilai signifikansi yaitu 0,103>0,05 yang dapat diartikan bahwa penggunaan Pendekatan Matematika Realistik memiliki variansi yang sama atau homogen.

Tabel 5. Uji Linearitas Skor Pretest dan Posttest Pendekatan Matematika Realistik

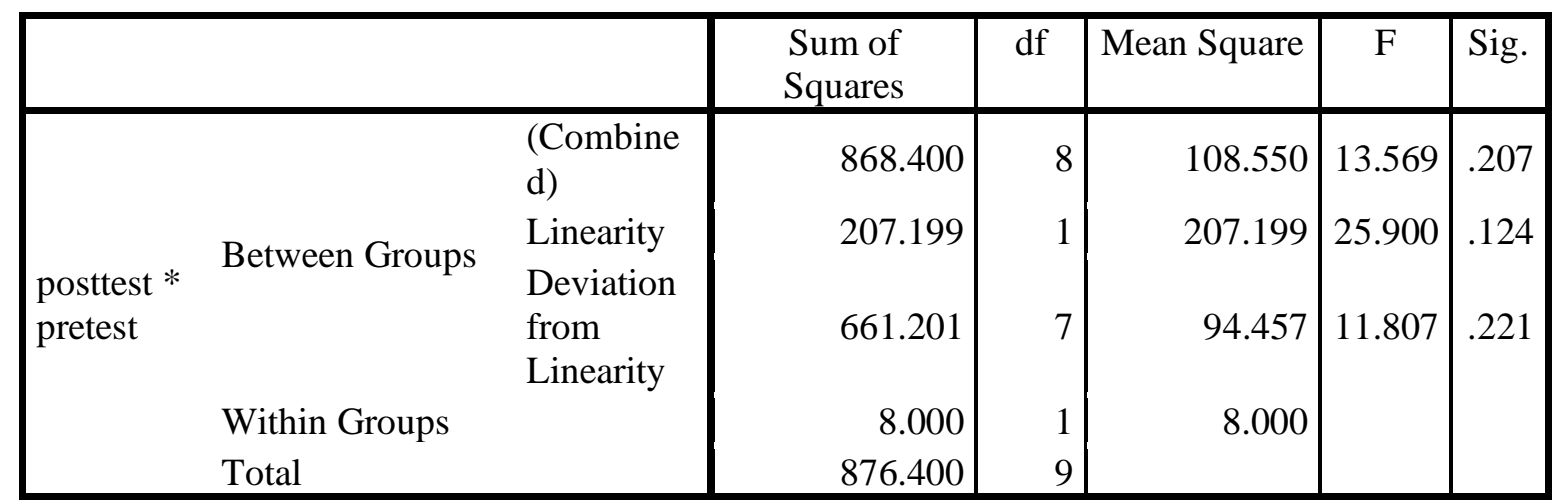

Sesuai dengan tabel di atas dapat disimpulkan bahwa dari uji linearitas skor pretest dan posttest Pendekatan Matematika Realistik memperoleh nilai signifikansi 0,221 > 0,05 yang dapat disimpulkan bahwa skor pretest dan posttest memiliki hubungan yang linear.

Tabel 6. Hasil Analisis Data Menggunakan Uji Ancova

\begin{tabular}{|c|r|r|}
\hline Mean & Std. Deviation & N \\
\hline 86.80 & 7.584 & 10 \\
\hline
\end{tabular}

Sesuai dengan hasil analisis data menggunakan uji Ancova yang dilakukan pada Pendekatan Matematika Realistik memiliki jumlah artikel sebanyak 10 dengan rata-rata 86,80. 
Tabel 7. Hasil Analisis Uji Ancova

\begin{tabular}{|c|c|c|c|c|c|c|}
\hline Source & $\begin{array}{c}\text { Type III Sum } \\
\text { of Squares }\end{array}$ & Df & Mean Square & F & Sig. & $\begin{array}{c}\text { Partial } \\
\text { Eta } \\
\text { Squared }\end{array}$ \\
\hline Corrected Model & $211.600^{\mathrm{a}}$ & 1 & 211.600 & 5.532 & .047 & .409 \\
Intercept & 75342.400 & 1 & 75342.400 & 1969.736 & .000 & .996 \\
Model & 211.600 & 1 & 211.600 & 5.532 & .047 & .409 \\
pembelajaran & 306.000 & 8 & 38.250 & & & \\
Error & 75860.000 & 10 & & & & \\
Total & 517.600 & 9 & & & & \\
Corrected Total & \multicolumn{2}{|c|}{} & & & \\
\hline
\end{tabular}

a. R Squared $=.409$ (Adjusted R Squared $=.335$ )

Sesuai dengan hasil uji Ancova yang terletak pada kolom Posstest di atas dapat disimpulkan bahwa signifikansi pada kolom Sig. sebesar 0,047. thitung yang diperoleh adalah 5.532 dan ttabel yang dapat diperoleh data diatas adalah 5,32. 5,32 didapat dengan rumus df $2=n-k$, df $2=10(1-1)$, df $2=10-2$, df $2=8$. Untuk menemukan hasil 5,32 terdapat pada ttabel yang disesuaikan berdasarkan jumlah sampel dikurangi jumlah variabel (bebas dan terikat), sehingga ditemukan hasil 5,32.

\section{Uji Hipotesis}

Berdasarkan hasil uji Ancova selanjutnya dilakukan uji hipotesis. Uji hipotesis dilakukan guna menentukan apakah hipotesis penelitian diterima atau ditolak. Berikut adalah hipotesis pada penelitian ini :

Ho : Pendekatan matematika realistic tidak berpengaruh terhadap kemampuan berpikir kritis pada matematika siswa di Sekolah Dasar.

Ha : Pendekatan matematika realistic berpengaruh terhadap kemampuan berpkir kritis pada matematika siswa di Sekolah Dasar.

Kriteria pengambilan keputusan :

1. Menggunakan koefisien Sig. dengan keputusan :

a. Jika nilai Sig. Hitung (probabilitas) $>0,05$ maka Ho diterima.

b. Jika nilai Sig. Hitung (probabilitas) < 0,05 maka Ho ditolak.

Berdasarkan hasil perhitungan hipotesis dengan menggunakan uji Ancova menggunakan Univariate yang menunjukkan nilai sig. sebesar 0,047 yang berarti lebih kecil dari $0,05(0,047<0,05)$. Hasil uji Ancova membuktikan $t$ hitung $>\mathrm{t}$ tabel yaitu 5.532>5,32 dan sig. 0,047<0,05 yang membuktikan bahwa Ho ditolak dan Ha diterima. Hal ini membuktikan bahwa Pendekatan Matematika Realistik berpengaruh pada kemampuan berpikir kritis pada matematika. Hasil ini memperkuat penelitian yang dilakukan oleh Arrum Meirisa, Ronal Rifandi dan Masniladevi (2018) yang menunjukkan bahwa Pendekatan Matematika Realistik memiliki pengaruh terhadap kemampuan berpikir kritis siswa. Dilihat dari hasil nilai rata-rata skor pretest sebesar 60 dan skor posttest sebesar 77.

Besarnya pengaruh yang dimiliki oleh Pendekatan Matematika Realistik ditinjau dari kemampuan berpikir kritis siswa dapat dilihat melalui hasil uji effect size. 
DOI : https://doi.org/10.31004/basicedu.v5i2.852

Tabel 8. Interpretasi Effect Size

\begin{tabular}{cc}
\hline Effect Size & Interprestasi \\
\hline $0<\mathrm{d}<0,2$ & Kecil \\
\hline $0,2<\mathrm{d} \leq 0,5$ & Sedang \\
\hline $0,5<\mathrm{d} \leq 0,8$ & Besar \\
\hline $\mathrm{d}>0,8$ & Sangat Besar \\
\hline
\end{tabular}

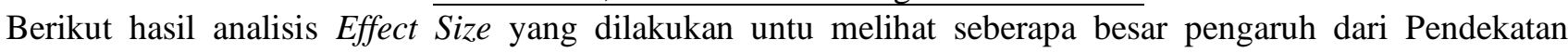
Matematika Realistik.

Tabel 9. Uji Effect Size Menggunakan Uji Ancova

\begin{tabular}{|c|c|c|c|c|c|c|}
\hline Source & $\begin{array}{c}\text { Type III Sum } \\
\text { of Squares }\end{array}$ & Df & Mean Square & F & Sig. & $\begin{array}{c}\text { Partial } \\
\text { Eta } \\
\text { Squared }\end{array}$ \\
\hline Corrected Model & $211.600^{\mathrm{a}}$ & 1 & 211.600 & 5.532 & .047 & .409 \\
Intercept & 75342.400 & 1 & 75342.400 & 1969.736 & .000 & .996 \\
Model & 211.600 & 1 & 211.600 & 5.532 & .047 & .409 \\
pembelajaran & 306.000 & 8 & 38.250 & & & \\
Error & 75860.000 & 10 & & & & \\
Total & 517.600 & 9 & & & & \\
Corrected Total & & &
\end{tabular}

a. R Squared $=.409$ (Adjusted R Squared $=.335)$

Berdasarkan dari tabel diatas melakukan uji effect size menggunakan uji Ancova menggunakan Pendekatan Matematika Realistik hasil yang tertera pada kolom Corrected Model yang diketahui Partial Eta Squared sebesar 0,409 dengan nilai Sig. sebesar 0,047. Hal ini menunjukkan bahwa Pendekatan Matematika Realistik memberi pengaruh tergolong sedang terhadap kemampuan berpikir kritis.

\section{KESIMPULAN}

Bersumber dari hasil penelitian dan juga pembahasan yang telah dijabarkan, sehingga dapat ditarik kesimpulan bahwa Pendekatan Matematika Realistik memiliki pengaruh yang signifikan terhadap kemampuan berpikir kritis siswa. Dapat dilihat melalui hasil pretest dan posstest yang memiliki selisih rerata sebesar 31,5. Berdasarkan perhitungan effect size yang diketahui Partial Eta Squared sebesar 0,409 dengan nilai Sig sebesar 0,047. Dari hasil didapatkan bahwa Pendekatan Matematika Realistik memiliki pengaruh tergolong sedang untuk meningkatkan kemampuan berpikir kritis.

\section{SARAN}

Dilihat dari simpulan diatas dapat diartikan bahwa dengan penggunaan Pendekatan Matematika Realistik memiliki pengaruh dalam meningkatkan kemampuan berpikir kritis pada pembelajaran matematika. Maka peneliti menganjurkan dengan Pendekatan Matematika Realistik dapat mendukung teori dan dapat dijadikan sebuah referensi oleh guru dan kepala sekolah pada proses pembelajaran di Sekolah Dasar dan sebagai sumber informasi bagi peneliti selanjutnya terutama dalam meningkatkan kemampuan berpikir kritis matematika siswa.

\section{DAFTAR PUSTAKA}

Arrum M., Ronal R., \& Masniladevi. (2018). "Pengaruh Pendekatan Matematika Realistik Indonesia (PMRI) Terhadap Ketrampilan Berpikir Kritis Siswa SD". Jurnal Gantang.

Dachi R. Alyakin. 2017. "Proses dan Analisis Kebijakan Kesehatan (Suatu Pendekatan Konseptual). CV. 
DOI : https://doi.org/10.31004/basicedu.v5i2.852

Budi Utama: Yogyakarta.

Dessy, N.A., \& Hamdan, H.B. 2017. Pengaruh Pembelajaran Matematika Realistik dengan Strategi Heuristik Krulik dan Rudnik terhadap Kemampuan Berfikir Kritis dan Prestasi Belajar Siswa Sekolah Dasar. Jurnal Madrasah Ibtidaiyah.

Dwi W.S., Firman, \& Neviyarni. 2019. Peningkatan Ketrampilan Berpikir Kritis Siswa Melalui Pendekatan Realistik di Sekolah Dasar. Jurnal Basicedu.

Kemdikbud. 2016. PISA 2016. Diakses pada tanggal 14 juli 2020 dari http://www.kemendikbud.go.id/main/blog/2016/12/peringkat-dan-capaian-pisaindonesiamengalamipeningkatan.html?m=1

Kusumaningsih, Diah. 2011. Upaya Meningkatkan Kemampuan Berpikir Kritis Siswa Kelas X-C SMAN 11 Yogyakarta Melalui Pembelajaran Matematika Dengan Pendekatan Contextual And Learning (CTL) Pada Materi Perbandingan Trigonometri. Skripsi. Yogyakarta: UNY.

Mirnawati, V. Karjiyati, Dalifa. (2020). Pengaruh Model RME Berbasis Etnomatematika Terhadap Kemampuan Berpikir Kritis Siswa Pada Pembelajaran Matematika Kelas V SDN Gugus 05 Kota Bengkulu. JURIDIKDAS.

Permendikbud No 22 Tahun 2016 tentang Standar Proses Pendidikan Dasar dan Menengah. Jakarta: Depdiknas.

Permendikbud No 24 Tahun 2016 tentang Kompetensi Inti dan Kompetensi Dasar pada Pendidikan Dasar dan Pendidikan Menengah. Jakarta: Depdiknas.

Puspitawedana, D. 2017. Efektifitas Pendekatan Matematika Realistik Untuk Meningkatkan Kemampuan Berpikir Kritis Siswa SD dalam Pembelajaran Matematika. Jurnal Pancar, 32-37.

Rosida, E.S. 2017. Proses Berpikir Kritis Siswa Sekolah Dasar pada Pembelajaran Geometri Melalui Pendekatan Matematika Realistik. S-1 PGSD Universitas Muhammadiyah Sidoarjo.

Ujiati, C., \& Dede, S.N. 2020. Peningkatan Kemampuan Berpikir Kritis Siswa Sekolah Dasar Melalui Realistic Mathematics Education. Seminar Nasional Pendidikan FKIP UNMA.

Vivi, P., Nofri, Y., \& Ronal, R. 2018. Dampak Pendekatan Realistic Mathematics Education Terhadap Keterampilan Berpikir Kritis Pada Siswa Sekolah Dasar. JUSTEK: Jurnal Sains dan Teknologi.

Wahyudi. 2017. Pembelajaran Matematika Realistik Sebagai Sebuah Cara Mengenal Matematika Secara Nyata. ResearchGate, 1-9.

Wijaya, A. 2012. Pendidikan Matematika Realistik Suatu Alternatif Pendekatan Pembelajaran Matematika. Yogyakarta: Graha Ilmu. 